\title{
THE TRIBAL PLACEMENT OF THE MONOSPECIFIC TROPICAL AFRICAN GENUS PETITIOCODON (RUBIACEAE) BASED ON MOLECULAR DATA AND MORPHOLOGY
}

\author{
J. TOSH ${ }^{1,2}$, P. DE BLOCK ${ }^{3}$, A.P. DAVIS ${ }^{2}$, S. DESSEIN ${ }^{3}$, \\ E. ROBBRECHT ${ }^{3} \&$ E.F. SMETS 4
}

\section{SUMMARY}

A first phylogenetic placement of Petitiocodon based on molecular sequence data from three plastid regions ( $a c c D$-psal, $r p l 16$ and $t r n L-F)$ is presented, in conjunction with a reassessment of morphology for the genus. Our results do not support an evolutionary affinity between Petitiocodon and Tricalysia (Coffeeae) as suggested by previous studies, but they confirm other research that Petitiocodon and Didymosalpinx are distinct genera. Placement of Petitiocodon in tribe Octotropideae is well-supported on the basis of molecular data and floral and carpological characters.

Key words: Octotropideae, African flora, accD-psal, rpl16, trnL-F, molecular phylogenetics, placentation.

\section{INTRODUCTION}

Petitiocodon Robbr. consists of a single species, Petitiocodon parviflora (Keay) Robbr., which is endemic to the mid and high altitude rain forest of south-east Nigeria and southwest Cameroon (Robbrecht 1988a). The species was first described by Keay (1958) in his treatment of west African Gardenia Ellis and Randia L. He placed this taxon within the newly erected genus Didymosalpinx Keay, along with four other species previously recognized in Gardenia. These five species were united by the presence of axillary inflorescences paired at the nodes and large, funnel-shaped corollas (Fig. 1).

Hallé (1968) commented on how Didymosalpinx parviflora Keay differed from the other species of Didymosalpinx in a number of characters. The vegetative parts of D. parviflora are pubescent, the flowers are subtended by bracts and bracteoles, the anthers are exserted, and the connective is elongated forming a sterile apical appendage (Hallé 1968). The other four Didymosalpinx species have glabrous vegetative parts, no bracts or bracteoles and the anthers are included in the corolla throat (Halle 1968, Robbrecht 1988a). Hallé (1968) suggested that 'Didymosalpinx parviflora' might share greater affinity with the Afro-Madagascan genus Tricalysia A.Rich. than with Didymosalpinx.

1) Laboratory of Plant Systematics, K.U.Leuven, Kasteelpark Arenberg 31, P.O. Box 2437, 3001 Leuven, Belgium.

2) Royal Botanic Gardens, Kew, Richmond, Surrey, TW9 3AE, United Kingdom.

3) National Botanic Garden of Belgium, Domein van Bouchout, 1860 Meise, Belgium.

4) Nationaal Herbarium Nederland, Leiden University branch, P.O. Box 9514, 2300 RA Leiden, The Netherlands. 

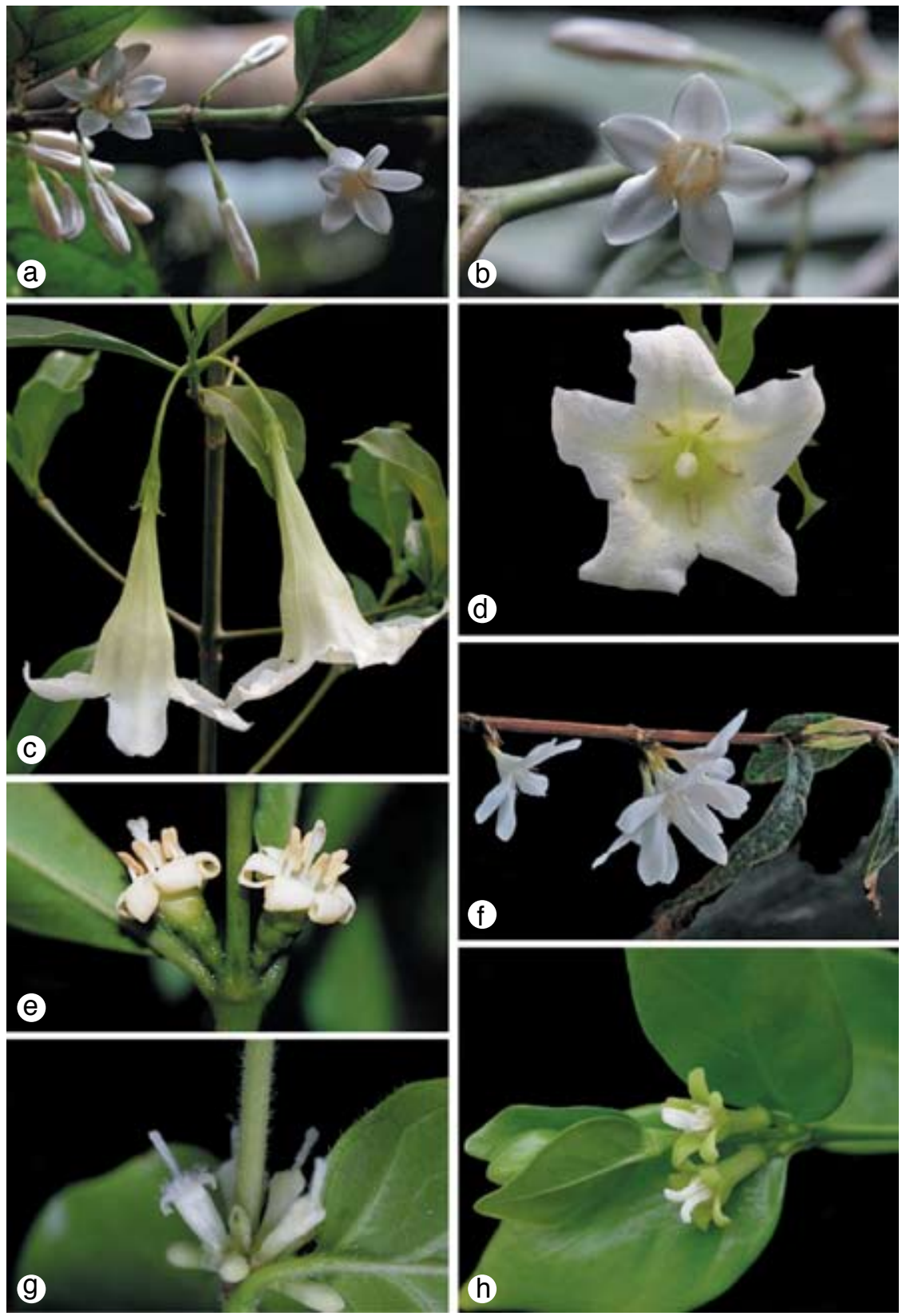

(9)

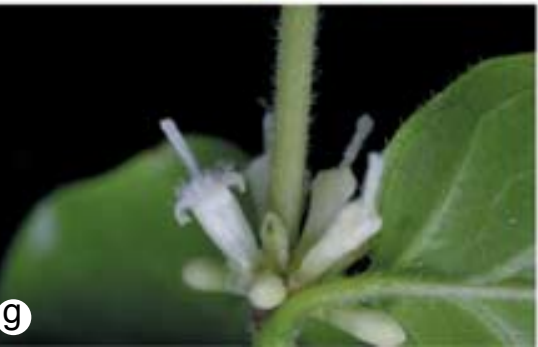

Fig. 1. Photographs of flowers of Petitiocodon parviflora and of presumed and genuine relatives. a. Flowering branch of Petitiocodon parviflora; b. front view of flower of Petitiocodon parviflora; c. flowering branch of Didymosalpinx norae (tentatively included in tribe Octotropideae); d. front view of flower of Didymosalpinx norae; e. flowering node of Tricalysia cryptocalyx Baker (tribe Coffeeae); f. flower of Feretia aeruginescens Stapf (tribe Octotropideae); g. flowering node of Polysphaeria parvifolia Hiern (tribe Octotropideae); h. flowering node of Kraussia floribunda Harv. (tribe Octotropideae). Photos: a, b by S. Dessein; c, d, f-h by F. Van Caekenberghe; e by P. De Block. 
Robbrecht revised the genus Tricalysia in a series of papers $(1979,1982,1983,1987)$, and conducted a comparative study of the morphology of 'Didymosalpinx parviflora' with respect to Didymosalpinx and Tricalysia (Robbrecht 1988a). He concluded that 'D. parviflora' shares habit, inflorescence arrangement and fruit and seed characters with Tricalysia, but differs from Tricalysia in corolla morphology, fruit size and the nature of the endocarp (for a full comparison see Robbrecht 1988a: table 1).

According to Robbrecht (1988a) the key characters of 'Didymosalpinx parviflora' include: paired axillary inflorescences; flowers subtended by pairs of bracts and bracteoles, with the lower pairs sometimes fused; corolla funnel-shaped, with contorted aestivation; anthers \pm included, attached below the corolla-throat, with connective elongated into a short sterile apical appendage; ovary 2-locular, each locule with an elongated placenta, longitudinally attached to the base and septum, with \pm 2 immersed lateral ovules, style exserted, (very) shortly bifid; fruits \pm spindle-shaped, with a \pm fleshy wall containing longitudinal sclerified strands, and one-seeded by abortion; seeds ellipsoidal with an inferior radicle.

Robbrecht (1988a) decided that 'Didymosalpinx parviflora' merited its own genus, namely Petitiocodon, within the tribe Gardenieae subtribe Diplosporinae Miq., an assemblage of taxa transferred from Ixoreae s.l. (Bremekamp 1934) by Robbrecht \& Puff (1986). Members of subtribe Diplosporinae were characterized by axillary inflorescences, bilocular ovaries, axile placentation with one to many ovules and an embryo with inferior radicle. The large funnel-shaped corollas of Petitiocodon parviflora were considered unique within subtribe Diplosporinae.

Our understanding of the tribal delimitation within Rubiaceae has changed considerably since the advent of molecular phylogenetics. A number of studies have led to the re-assessment of tribal boundaries, and this is particularly the case for the 'Gardenieae-Ixoreae complex' investigated by Robbrecht \& Puff (1986). The molecular studies of Andreasen \& Bremer $(1996,2000)$ and Persson (2000) demonstrated that several members of the Gardenieae subtribe Diplosporinae are in fact closely related to Coffea L. and Psilanthus Hook.f. The study of Andreasen \& Bremer (2000) resulted in an enlargement of the tribe Coffeeae, modified to include Diplospora DC., Sericanthe Robbr., Tricalysia and Discospermum Dalzell. Diplospora and Tricalysia were retransferred to Coffeeae on the basis of molecular data, Sericanthe and Discospermum based on their morphological affinity to Tricalysia and Diplospora, respectively. Bridson \& Verdcourt (2003) further modified the concept of Coffeeae, on the basis of morphological observations and unpublished data, to include Argocoffeopsis Lebrun, Belonophora Hook.f. and Calycosiphonia Pierre ex Robbr., and placed Gardenieae subtribe Diplosporinae in the synonymy of Coffeeae.

Davis et al. (2007) investigated the delimitation and characterization of the tribe Coffeeae, using a morphological and molecular dataset. Their study included all of the taxa previously placed in the tribe by Andreasen \& Bremer (2000) and Bridson \& Verdcourt (2003), as well as the three remaining members from the Gardenieae subtribe Diplosporinae (Petitiocodon, Nostolachma T.Durand and Xantonneopsis Pit.). In addition, their sampling included a wide selection of taxa from subfamily Ixoroideae Raf. s.s. For Petitiocodon, Nostolachma and Xantonneopsis, they were unable to obtain undegraded DNA from herbarium leaf material, and as a result the phylogenetic placement of these three genera was assessed on the basis of a combined molecular 
and morphological investigation. Nostolachma was accepted within the tribe Coffeeae, Xantonneopsis was placed in Octotropideae (BS (= Bootstrap Support) 69) and Petitiocodon was provisionally placed within Gardenieae, although the support for this was very low $(\mathrm{BS}<50)$.

In the present study, we aim to investigate the phylogenetic placement of Petitiocodon based on sequence data of three plastid regions (accD-psal, rpll6 and trnL-F). In addition, morphological observations are carried out that complement Robbrecht's previous work. In particular a study of placentation is made on recently collected herbarium vouchers and alcohol preserved material. This is the first study that includes molecular data for this enigmatic species.

\section{MATERIALS AND METHODS}

\section{Taxon sampling}

We included three accessions of Petitiocodon parviflora, two collected in the field (Cameroon) and one obtained from a herbarium sample (Gereau 5497, BR). To test whether P. parviflora is more closely related to Tricalysia or Didymosalpinx, we included sequence data for a large selection of Coffeeae taxa (i.e. former members of Gardenieae subtribe Diplosporinae) and produced novel sequence data for Didymosalpinx norae (Swynn.) Keay. These data were combined with sequences from representatives of Octotropideae, Pavetteae and Gardenieae, which collectively form the Gardenieae alliance (Robbrecht \& Manen 2006). Vanguerieae (Peponidium (Baill.) Arènes and Pyrostria Comm. ex A.Juss.) and Ixoreae (Ixora L. and Doricera Verdc.) were selected as the outgroup in this investigation, based on broader molecular studies of the Rubiaceae (see Introduction).

In this study we incorporate novel sequence data (32 new sequences) with selected sequences taken from Davis et al. (2007) and Tosh et al. (In press). A complete list of accessions is given in Appendix 1.

\section{Morphological features}

The taxa under investigation were subject to thorough morphological investigations (Robbrecht \& Puff 1986, Robbrecht 1986, 1988a). Additional LM and SEM observations were made to investigate the placentation of Petitiocodon (spirit material, Dessein \& Sonké 1592 from Cameroon). Methods for microtome sectioning and SEM-investigations follow those described by Igersheim (1993). A fruit dissection was carried out on material from Cheek et al. 3454 (K) and Nemba et al. 570 (K).

\section{DNA isolations, PCR amplification and sequencing}

DNA samples were obtained from recent silica gel collections and leaf material taken from herbarium specimens (BR, K), or alternatively from living collections at the National Botanic Garden of Belgium (Appendix 1). Fresh leaf material and silica gel samples were isolated using a modified DNA Mini-extraction protocol (RBG Kew protocol, unpubl. data). In the case of herbarium material, DNA was obtained by a modification of the 2X CTAB protocol of Doyle \& Doyle (1987). All DNA isolations 
Table 1. Amplification primers for accd-psal, rpl16 and $\operatorname{trn} L-F$ plastid regions.

\begin{tabular}{llll}
\hline Region & Primer & Primer sequence (5'-3') & Reference \\
\hline accD-psal & Forward (769 F) & GGA AGT TTG AGC TTT ATG CAA ATG & Mendenhall 1994 \\
& Reverse (75 R) & AGA AGC CAT TGC AAT TGC CGG AAA & \\
rpl16 & Forward (71f) & GCT ATG CTT AGT GTG TGA CTC GTT G & Jordan et al. 1996 \\
& Reverse (1661r) & CGT ACC CAT ATT TTT CCA CCA CGA C & \\
& Reverse (1516r) & CCC TTC ATT CTT CCT CTA TGT TG & Shaw et al. 2005 \\
& Internal forward & GTA AGA AGT GAT GGG AAC GA & Davis et al. 2007 \\
& Internal reverse & TCG TTC CCA TCA CTT CTT AC & \\
\multirow{2}{*}{ rnL-F } & Forward (c) & CGA AAT CGG TAG ACG CTA CG & Taberlet et al. 1991 \\
& Reverse (f) & AAT TGA ACT GGT GAC ACG AG & \\
\hline
\end{tabular}

were purified using Nucleospin columns (Macherey-Nagel) according to the manufacturers instructions, to remove potential PCR inhibitors.

Amplification of the $\operatorname{trnL}-F$, rpll6 and accD-psal plastid regions were carried out using the primers listed in Table 1. Internal primers were required for complete amplification of some $r p l 16$ sequences. PCR and cycle sequencing reactions were performed using a Perkin Elmar GenAMP® 9700 thermocycler machine. Amplification of all three regions was carried out using the following profile: $94{ }^{\circ} \mathrm{C}$ for $3 \mathrm{~min} ; 32$ cycles of $94^{\circ} \mathrm{C}$ for $1 \mathrm{~min}, 51^{\circ} \mathrm{C}$ for $1 \mathrm{~min}, 72^{\circ} \mathrm{C}$ for $2 \mathrm{~min}$; final extension of $72{ }^{\circ} \mathrm{C}$ for $7 \mathrm{~min}$. PCR master mixes were prepared using GoTaq ${ }^{\circledR}$ DNA polymerase, $5 \mathrm{X}$ reaction buffer, $1.5 \mu \mathrm{l} 25 \mathrm{mM} \mathrm{MgCl}{ }_{2}$ and $2.5 \mu \mathrm{l}$ dNTP's (Promega, Maddison, WI, USA). All amplification products were purified using Nucleospin purification columns. Cycle sequencing reactions were carried out using BigDye Terminator Mix (Applied Biosystems, Inc., Warrington, Cheshire, UK) and 26 cycles of: $10 \mathrm{~s}$ at $96{ }^{\circ} \mathrm{C}, 5 \mathrm{~s}$ at $50{ }^{\circ} \mathrm{C}$ and $4 \mathrm{~min}$ at $60^{\circ} \mathrm{C}$. Cycle sequence products were purified using an automated robot (Beckman Coulter Biomek NX S8) with the Promega Magnesil clean up system. Sequencing was performed using an AB 3730 DNA analyzer (Applied Biosystems). Electropherograms were assembled and edited using the Staden software package (Staden et al. 1998) and aligned manually in MacClade (version 4.04 (c) Maddison \& Maddison 2002).

\section{Phylogenetic analyses}

Phylogenetic analyses were performed on the three separate plastid datasets and a combined three-region plastid matrix, using maximum parsimony and Bayesian inference. In all analyses, potential phylogenetically informative indels were coded according to the 'simple indel coding' method of Simmons \& Ochoterena (2000).

\section{Maximum parsimony}

Heuristic tree searches were carried out in PAUP* version 4.0b10 (Swofford 2003). Each analysis consisted of tree-bisection-reconnection (TBR) branch swapping on 10,000 random taxon sequence addition replicates, holding 10 trees at each step, with delayed transformation (DELTRAN) optimization, MulTrees in effect and saving no 
more than 10 trees per replicate. Support values for clades recovered in the analyses were estimated using bootstrap analysis (Felsenstein 1985). One thousand replicates of 100 random sequence additions, with TBR swapping, saving 10 trees per replicate were performed in PAUP*. We interpreted bootstrap values greater than $85 \%$ as being well supported, $75-84 \%$ as being moderately supported and $50-74 \%$ as having low support.

\section{Bayesian inference}

The most appropriate substitution model for each plastid region was selected using Modeltest v.3.06 (Posada \& Crandall 1998) under the Akaike Information Criterion. The HKY + I nucleotide substitution model was selected for trnL-F and the HKY + I + G model was selected for $a c c D$-psal and rpll6. The restriction site (binary) model was implemented for indel data, following the recommendation of Ronquist et al. (2005). Two independent Bayesian searches, each consisting of two simultaneous parallel analyses, were carried out using MrBayes 3.1 (Huelsenbeck \& Ronquist 2001). Four Markov Chains (one cold, three heated) were run simultaneously in each analysis for a total of 2,000,000 generations, with tree sampling occurring every 100 generations. The initial $25 \%$ of trees were discarded as a conservative 'burn in'. The post 'burn in' trees from the four independent analyses were pooled together and summarized by majority rule consensus using PAUP* version 4.0b10 (Swofford 2003). Nodes with posterior probabilities of 0.95 or higher were considered well supported.

\section{RESULTS}

\section{Genetic variation of plastid regions}

Low levels of genetic variation across all three regions enabled sequences to be aligned without difficulty. The rpl16 region proved to be the most variable of the three plastid regions, with $10.04 \%$ of the total number of characters being potentially parsimony informative (Table 2). However, rpll6 also proved to be the most difficult marker to amplify due to two poly-A stretches, one near the 5' end and the other near the 3' end of the sequence. Considerable length variation was observed in both the accD-psal and rpl16 regions (Table 2). Peponidium and Pyrostria species (outgroup taxa from tribe Vanguerieae) shared a 274 base pair insertion/deletion in the rpl16 region, which accounted for a large amount of the total length variation observed in this region. In the case of accD-psal, three genera (Didymosalpinx, Empogona and Petitiocodon) contained large, though non-homologous, deletions in the aligned sequence matrix. The $a c c D$-psal region was rich in potentially informative insertion and deletion events, and 16 indels were coded in the final analysis (Table 2).

\section{Phylogenetic analyses}

The tree topologies of the three individual plastid analyses were examined by eye and found to be consistent. The three datasets were then combined for all subsequent analyses. The aligned combined matrix had a total length of 3464 base pairs, of which 316 characters $(9.03 \%)$ were potentially phylogenetically informative. The combined analysis also included 37 indel characters. 
Table 2. Tree statistics and characterization of individual and combined datasets.

\begin{tabular}{lrrrr}
\hline & accd-psal & \multicolumn{1}{c}{ rpl16 } & trnL-F & Combined \\
\hline Number of taxa & 45 & 44 & 45 & 46 \\
Total length (base pairs) & 1319 & 1265 & 880 & 3464 \\
Sequence length variation & $694-1084$ & $898-1121$ & $786-827$ & - \\
Number of constant characters & 1121 & 1038 & 752 & 2911 \\
Number of potentially PI characters & 116 & 127 & 73 & 316 \\
(\% of total characters) & $(8.69)$ & $(10.04)$ & $(8.30)$ & $(9.03)$ \\
Number of PI indels & 16 & 11 & 10 & 37 \\
Tree length & 291 & 348 & 174 & 821 \\
CI & 0.852 & 0.802 & 0.845 & 0.821 \\
RI & 0.875 & 0.849 & 0.897 & 0.861 \\
Number of trees saved & 72642 & 207 & 22803 & 457 \\
\hline
\end{tabular}

The maximum parsimony (MP) analysis of the combined plastid dataset generated 457 most parsimonious trees with a length of 821 steps (Table 2). The topologies of the MP strict consensus tree and the Bayesian majority rule consensus tree were more or less congruent with each other, only differing in the placement of the genus Rutidea DC. (Pavetteae).

In all three individual plastid analyses (trees not shown) and the combined analyses (Fig. 2), Petitiocodon is sister to Polysphaeria Hook.f., within a clade containing Canephora Juss., Chapelieria A.Rich., Cremaspora Benth. and Didymosalpinx (hereafter referred to as Clade I, Fig. 2). In the combined analyses, the sister relationship between Petitiocodon and Polysphaeria is supported by a bootstrap value (BS) of $96 \%$ and posterior probability (PP) of 1.00. The clade of Canephora and Chapelieria is strongly supported (BS 100, PP 1.00), although there is only weak support for its sister relationship to the clade of Petitiocodon and Polysphaeria (BS 73). There is strong support for the clade containing Canephora, Chapelieria, Cremaspora, Petitiocodon and Polysphaeria (BS 93, PP 1.00). The sister relationship of Didymosalpinx to all the other taxa within Clade I is also strongly supported (BS 90, PP 0.99).

In the Bayesian analysis, Rutidea (Pavetteae) is sister to Clade I, although this relationship receives no support (PP 0.60). In the MP analysis (not shown), Rutidea is sister to the clade of Gardenieae taxa, but again this relationship is not supported (BS $<50$ ). The sister relationships of Schumanniophyton to Gardenia and Hyperacanthus is not supported (BS < 50, PP 0.77), as is the case for the sister relationship between Gardenia and Hyperacanthus (BS < 50, PP 0.90).

The monophyly of Coffeeae (Clade II) is strongly supported (BS 99, PP 1.00), as is the clade of Coffea and Psilanthus (BS 100, PP 1.00), which is sister to the remaining Coffeeae taxa (BS 86, PP 1.00). Argocoffeopsis and Calycosiphonia form a wellsupported clade (BS 100, PP 1.00), as do Empogona and Diplospora (BS 100, PP 1.00) and Discospermum and Xantonnea (BS 97, PP 1.00). The monophyly of Sericanthe (BS 100, PP 1.00) and Tricalysia (BS 100, PP 1.00) are confirmed. There is strong BS (87) and high PP (1.00) for the sister relationship between Bertiera Aubl. and Coffeeae. 


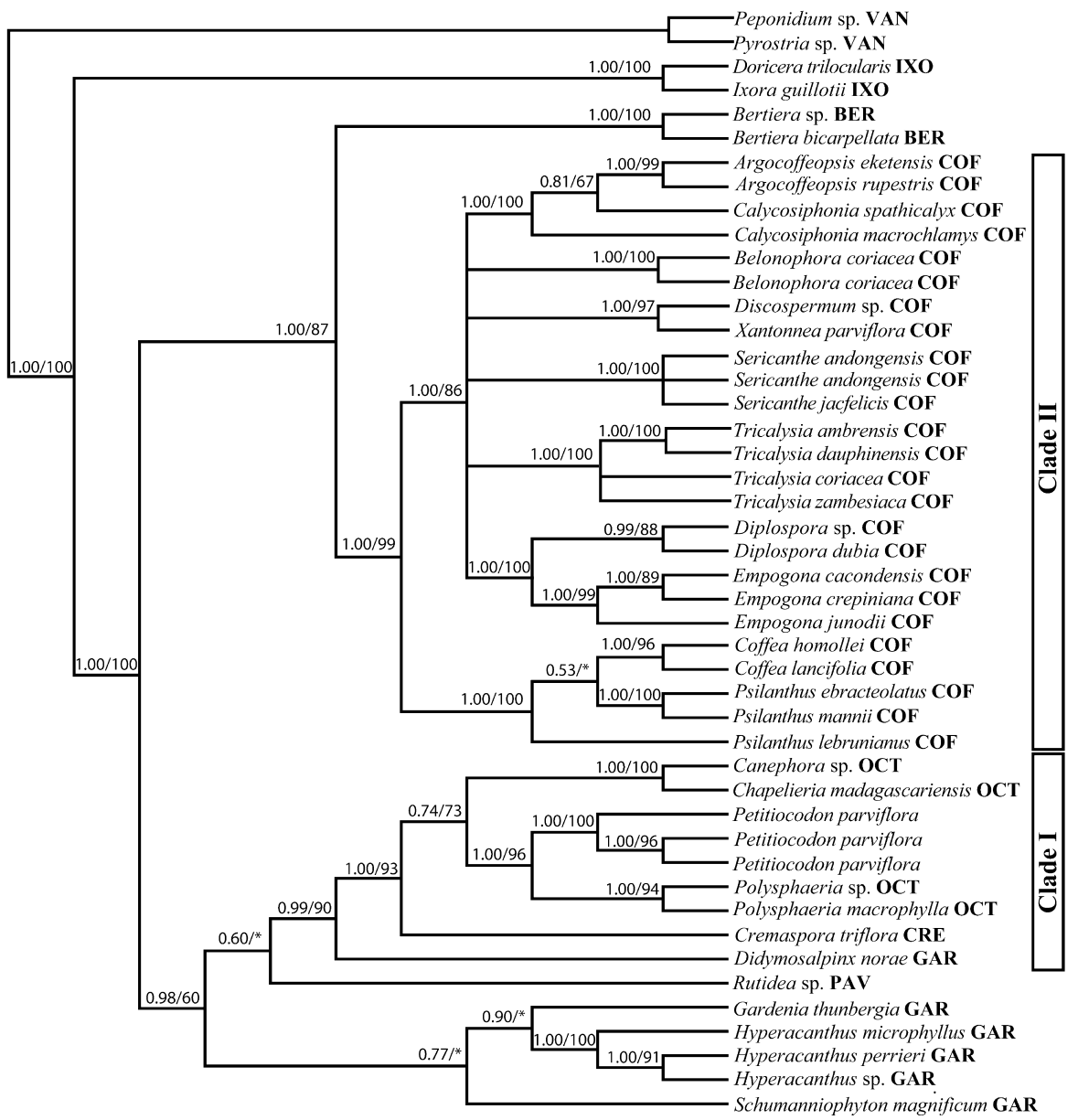

Fig. 2. Bayesian majority rule consensus tree. Support values (Bayesian Posterior Probabilities/ MP Bootstrap) are indicated above the branches. Asterisks (*) denote nodes that have bootstrap support $<50$ in the MP analysis. Tribal ranking is annotated after species names. VAN - Vanguerieae, IXO - Ixoreae, BER - Bertiereae, CRE - Cremasporeae COF - Coffeeae, OCT - Octotropideae, PAV - Pavetteae, GAR - Gardenieae. Clade I corresponds to the Octotropideae sensu Robbrecht \& Manen (2006), Petitiocodon and Didymosalpinx. Clade II corresponds to the tribe Coffeeae.

Ixora and Doricera (tribe Ixoreae), which Mouly (2007) considers to be congeneric, are sister (BS 100, PP 1.00) to all members of the 'Gardenieae alliance' (sensu Robbrecht \& Manen 2006).

\section{Morphological observations}

The paired axillary inflorescences of $P$. parviflora are placed 3-6 $\mathrm{mm}$ above the node and are thus supra-axillary (Fig. 1a). The flowers are hermaphrodite and 5-merous, and the corolla lobes in bud (i.e. aestivation) are contorted to the left (Fig. 1a, b). The corolla has a rather thick, waxy texture, and the inside of the corolla tube is finely 

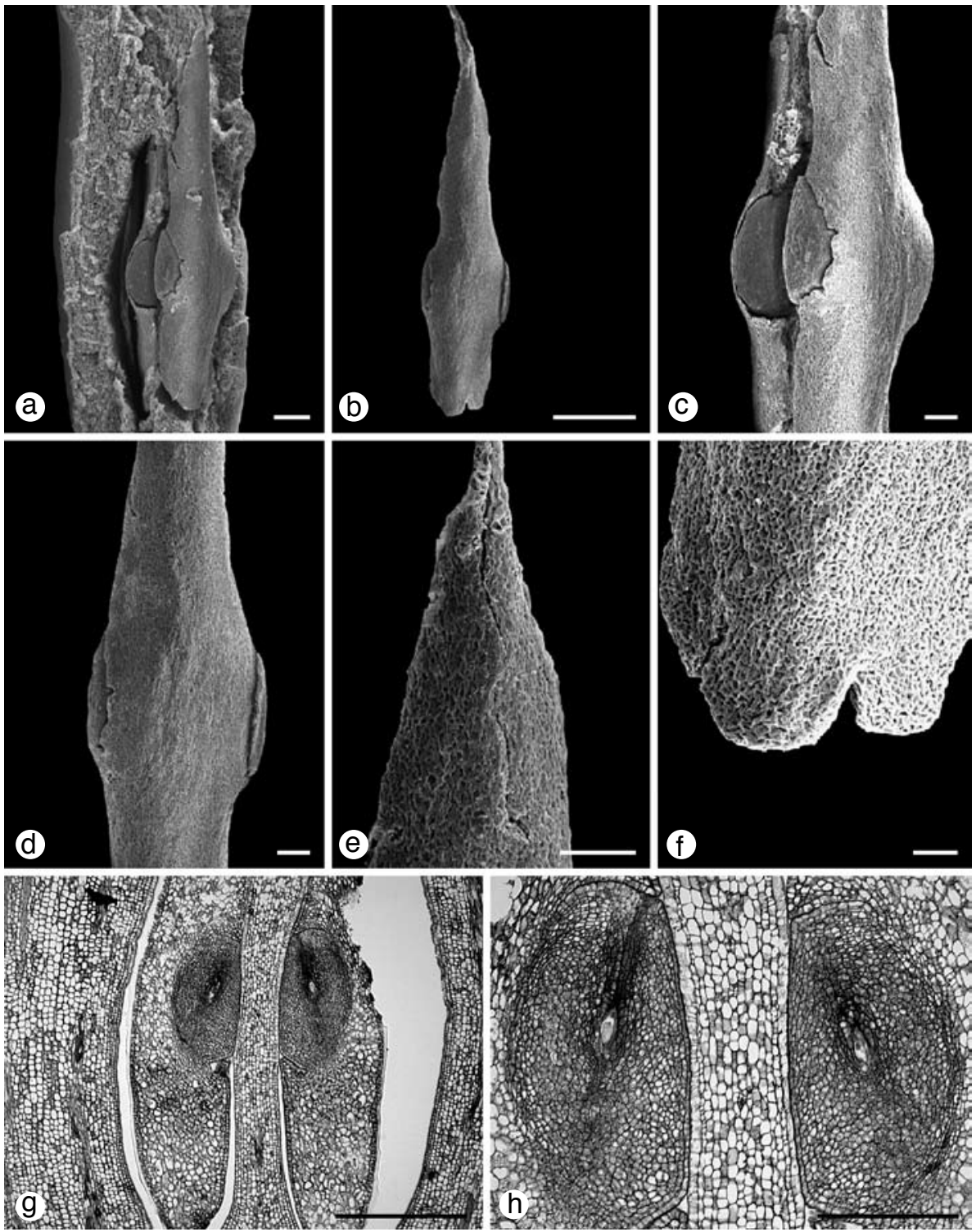

Fig. 3. Placentation in Petitiocodon parviflora. a. Opened bilocular ovary showing two placentas; b. front view of placenta with two lateral ovules; c. detail of central part of the two placentas showing the insertion of the ovules; d. detail of front view of the placenta showing the position of the two ovules; e. elongated tip of the placenta; $f$. base of the placenta; g. longitudinal section of bilocular ovary perpendicular to septum showing the two placentas; $h$. detail of $g$, showing the ovules with superior micropyles directed towards the septum. - Scale bars: $\mathrm{a}, \mathrm{h}=200 \mu \mathrm{m} ; \mathrm{b}, \mathrm{g}=500 \mu \mathrm{m} ; \mathrm{c}-\mathrm{e}$ $=100 \mu \mathrm{m} ; \mathrm{f}=50 \mu \mathrm{m}$. 


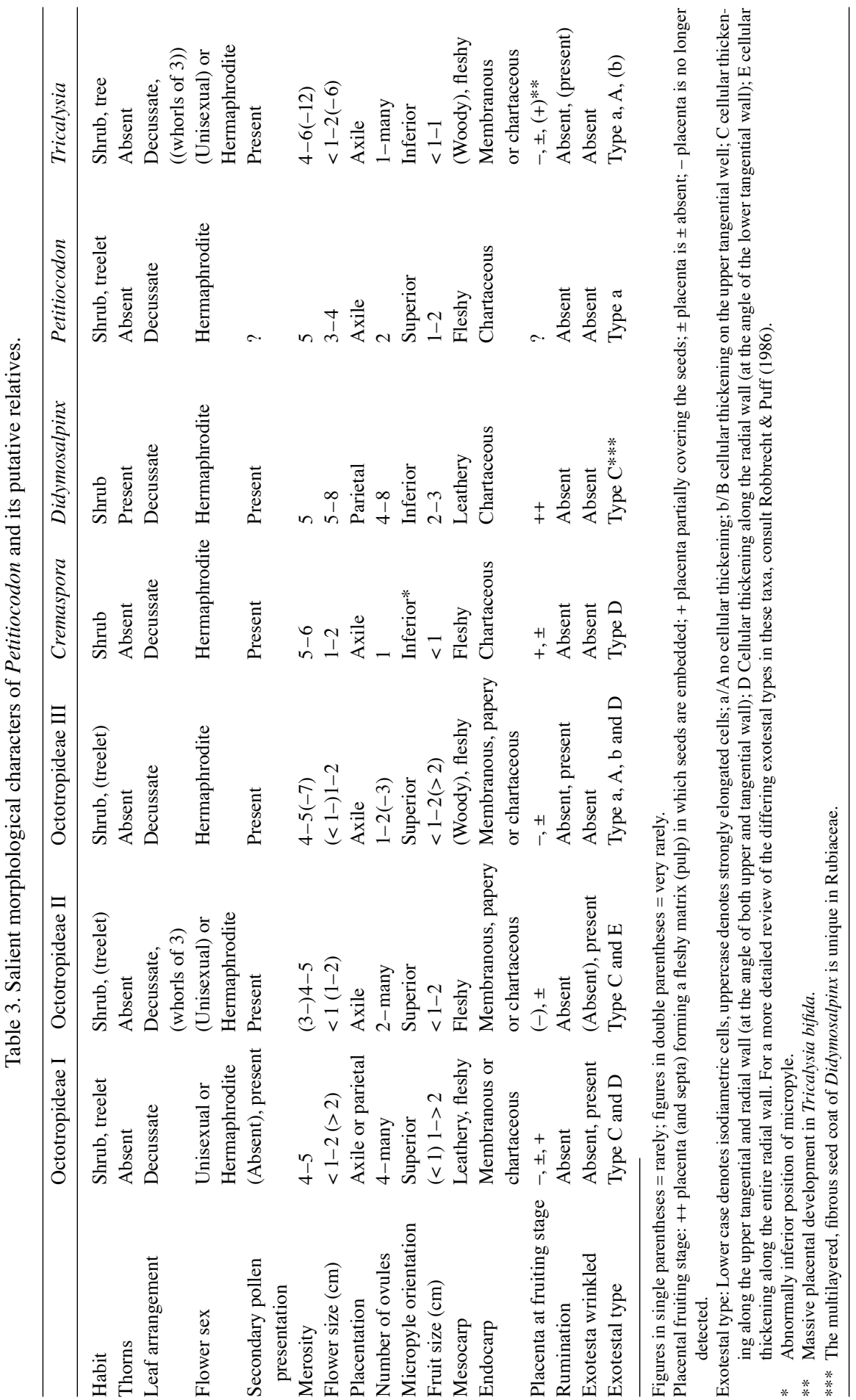


pubescent over its entire surface apart from a glabrous area about $2 \mathrm{~mm}$ from the base. The style is spindle-shaped, 10-ridged (where the anthers sit in 5 by 2 anther thecae, when the flower is in bud), and glabrous (Fig. 1b). The stigmatic lobes are adnate for most of their length and only the tips separate in mature styles (before maturity the tips are adnate). The stigmatic lobes are fused for $1 / 3$ to $3 / 5$ of their entire length, with two longitudinal grooves covered with papillae where they adjoin. The style and anther morphology strongly suggests secondary pollen presentation (Puff et al. 1996).

The ovary of $P$. parviflor $a$ is bilocular, with each locule containing a massive elongated axile placenta with two lateral ovules (Fig. 3a-f). The placenta is more or less spindle-shaped, widest in its lower half and becoming gradually narrower in the upper half. The tip is long acuminate and divided longitudinally for roughly half of the length above the insertion of the ovules (Fig. 3b, e). The base is rounded and divided longitudinally for a very short distance (Fig. 3f). The placenta is attached to the septum almost over its entire length. In the lower half of each placenta there are two lateral ovules, more or less immersed in the placenta. Each ovule possesses a superior micropyle directed towards the septum (Fig. 3g, h).

Mature and spirit preserved fruits remain unavailable, and so detailed embryographical and carpological observations could not be made. However, dissection of dried fruits revealed that each fruit contains two narrowly hemi-ellipsoidal seeds, with a smooth seed coat and entire endosperm.

\section{DISCUSSION}

\section{The phylogenetic position of Petitiocodon parviflora}

The results of our phylogenetic analyses do not support a close association between Petitiocodon parviflora and Tricalysia (Hallé 1968) or genera previously placed within Gardenieae subtribe Diplosporinae (Robbrecht 1986), i.e. Coffeeae (Davis et al. 2007). Our results support the claim by Halle (1968) that P. parviflora does not belong in Didymosalpinx. Although we did not sequence the type species of Didymosalpinx (D. abbeokutae (Hiern) Keay), with the exception of P. parviflora the delimitation of the genus has never been doubted (see Introduction). Indeed, the genus is morphologically homogeneous and contains only four Afrotropical species. Didymosalpinx norae and P. parviflora are both placed in our Clade I, but they do not share a sister relationship (Fig. 2).

Instead, our data imply that P. parviflora is sister to Polysphaeria of tribe Octotropideae, a relationship that receives considerable support in the analyses (BS 96, PP 1.00). Even though our taxon sampling of Octotropideae, Pavetteae and Gardenieae is not exhaustive, Clade I receives high levels of support in both maximum parsimony and Bayesian Analyses (BS 90, PP 0.99) inferring a close relationship between P. parviflora and Octotropideae. In addition, the present study further confirms the sister group relationship between Cremaspora and Octropideae, as previously shown by Andreasen \& Bremer (2000), Persson (2000) and Robbrecht \& Manen (2006).

Table 3 is adapted from the comparative morphological dataset of Robbrecht \& Puff (1986) and compares selected morphological characters between P. parviflora, other 
members of Clade I and Tricalysia. In their survey of the Gardenieae and related tribes, Robbrecht \& Puff (1986) recognized three informal groups within the Octotropideae (then known as Hypobathreae): Octotropideae I, a group of presumably primitive taxa characterized by large fruits with numerous seeds and thickening of the radial and outer $( \pm$ inner) tangential walls of the exotestal cells; Octotropideae II, a group of core taxa with smaller fruits, relatively few ovules and thickening of the radial walls of the exotestal cells; and Octotropideae III, a group of presumably advanced taxa with small fruits, one or few ovules, ruminate endosperm and little or no thickening of the exotestal cells. Robbrecht (1980) concluded that the Octotropideae as a whole form 'a highly natural group, perhaps one of the most natural ones of the Rubiaceae'.

The salient characters of Octotropideae are (adapted from Robbrecht 1988b, Bridson \& Verdcourt 2003 and Ruhsam \& Davis 2007): petioles articulated (rarely not); inflorescences paired at the nodes, axillary or supraxillary; flowers hermaphrodite (rarely functionally unisexual) with secondary pollen presentation; corolla bell- or salver-shaped, lobes contorted to the left; ovary 2-locular (rarely 1-locular); placentation axile or rarely parietal (Villaria Rolfe); placentas small or large and fleshy; ovules 1-many, often (but not exclusively) pendulous, if more than two ovules per locule then in two distinct rows; micropyle/radicle usually superior; style simple or club- to spindle-shaped, entire or 10 ridged/winged, adnate at the apex and sometimes very shortly bifid, or bifid; fruits mostly small, fleshy or rarely leathery; seeds 1-several (rarely more than 10); endosperm ruminate or entire; testa often appearing fibrous with a minute fingerprint-like pattern at low magnifications; exotesta mostly folded with regard to endotesta, composed of elongated cells with thickenings along the radial walls or less often isodiametric, parenchyma-like.

Based on our anatomical and morphological survey, it is now clear that $P$. parviflora has many of the salient characters of Octotropideae, including: inflorescences paired and supra-axillary; flowers hermaphrodite with secondary pollen presentation; corolla bell-shaped, lobes contorted to the left; placentation axile, ovary 2-locular; ovules 2 per locule, micropyle superior and directed towards the septum (e.g. Fig. 3g, h); radicle superior; style spindle-shaped, 10-ridged, adnate along its entire length but becoming very shortly bifid at maturity; fruits fleshy to leathery; seeds 2 per fruit; endosperm entire. The details of the seed-coat are as yet unknown.

Our observations on ovary, style and fruit morphology are particularly pertinent to our reassessment of Petitiocodon. In his study of P. parviflora Robbrecht (1988a) gave the orientation of the radicle in the seed as inferior (micropyle downward) but we now know that it is superior (micropyle upward). The orientation of the micropyle is a valuable systematic character in the Rubiaceae and is superior in Octotropideae, except in rare cases (Robbrecht \& Puff 1986, Ruhsam \& Davis 2007). Robbrecht (1988a: fig. 2d) noted the style of $P$. parviflora simply as 'exserted, (very) shortly bifid'. Our examinations based on living and alcohol preserved specimens show that the style is spindle-shaped, 10-ridged, very shortly bifid at maturity. Within the tribes of Ixoroideae s.s. this type of style is consistent in Bertiereae (K.Schum) Bridson, frequent in Octotropideae (e.g. Chapelieria, Kraussia Harv.), rare in Pavetteae and Gardenieae s.l., and absent in Coffeeae, Cremasporeae (Verdc.) S.P.Darwin, Ixoreae A.Gray and Vanguerieae Dumort. Our observation of two-seeded fruits in Petitiocodon indicates 
that the one-seeded condition (by abortion) of fruits as mentioned by Robbrecht (1988a: table 1) may not be consistent for the genus.

Whereas the Octotropideae were once thought to possess a more or less uniform ovary morphology (pendulous ovules attached to an apical placenta; Robbrecht \& Puff 1986), we now know this is not the case for all representatives of the tribe. Petitiocodon is one example, as is the Madagascan genus Flagenium Baill. In this genus Ruhsam \& Davis (2007) described a placenta bearing two distinct rows of ovules, with the uppermost ovules erect and the lower ovules pendulous, and in some species there are also a set of lateral ovules. However, complete data on ovary morphology for the Octotropideae are lacking, and variation is obviously greater than previously recorded (Robbrecht $\&$ Puff 1986). In some respects the ovary morphology of Petitiocodon is similar to other Octotropideae, and in particular Kraussia (Octotropideae III). Kraussia speciosa Bullock has a large (hemi-ellipsoid not spindle-shaped) placenta and two ovules per locule (Bridson \& Verdcourt 1988) but in contrast to Petitiocodon, each placenta is only attached for a small part to the apex of the septum. Kraussia and Petitiocodon also both possess non-articulated petioles, a 10-ridged/winged style, and seeds with entire endosperm. In our molecular analyses Petitiocodon is sister to Polysphaeria (Octotropideae III), although a close relationship is not envisaged following a more complete sampling of Octotropideae, as Polysphaeria has an ovary with a small placenta attached to the apex of the septum, a single ovule per locule, an undivided style, and seeds with ruminate endosperm (Robbrecht \& Puff 1986, Bridson \& Verdcourt 1988, 2003).

Based on our morphological reassessment it is clear that Petitiocodon falls within Octotropideae and has no association with other tribes of the Ixoroideae sampled in this investigation. This assumption is strongly supported by our molecular data, which convincingly place Petitiocodon with representatives of Octotropideae (e.g. BS 96, PP $1.00)$.

\section{Conclusions}

This study provides the first phylogenetic placement of Petitiocodon based on molecular sequence data. Our results do not support an evolutionary affinity between Petitiocodon and Tricalysia but they confirm that Petitiocodon and Didymosalpinx are distinct genera. Furthermore, molecular and morphological data strongly indicate that Petitiocodon belongs to the Octotropideae. Therefore, tribal delimitation of the Octotropideae is amended to incorporate this rare monospecific African genus.

\section{ACKNOWLEDGEMENTS}

Special thanks go to B. Sonké, from the Yaounde I University, Cameroon, for his participation in the collecting of new material of Petitiocodon parviflora. We would also like to thank two anonymous reviewers and Laura Kelly (RGBE) for their helpful comments and suggestions on the paper. Finally, we thank Frank Van Caekenberghe, for providing some of the photographs. This research was supported financially by grants from the Fund for Scientific Research, Flanders (F.W.O., G.0250.05 and G.0268.04). 


\section{REFERENCES}

Andreasen, K. \& B. Bremer. 1996. Phylogeny of the subfamily Ixoroideae (Rubiaceae). Opera Bot. Belg. 7: 119-138.

Andreasen, K. \& B. Bremer. 2000. Combined phylogenetic analysis in the Rubiaceae-Ixorideae: morphology, nuclear and chloroplast DNA data. Amer. J. Bot. 87: 1731-1748.

Bremekamp, C.E.B. 1934. A monograph of the genus Pavetta L. Repert. Spec. Nov. Regni Veg. 37 : 1-208.

Bridson, D.M. \& B. Vercourt. 1988. Rubiaceae, Part 2. In: R. M. Polhill (ed.), Flora of Tropical East Africa: 415-447. Balkema, Rotterdam, The Netherlands.

Bridson, D.M. \& B. Vercourt. 2003. Rubiaceae. In: G.V. Pope (ed.), Flora Zambesiaca, Vol. 5, 3: 379-720. Royal Botanic Gardens, Kew.

Davis, A.P., M. Chester, O. Maurin \& M.F. Fay. 2007. Searching for the relatives of Coffea (Rubiaceae, Ixoroideae): the circumscription and phylogeny of Coffeeae based on plastid sequence data and morphology. Amer. J. Bot. 94: 313-329.

Doyle, J.J. \& J.L. Doyle. 1987. A rapid DNA isolation procedure for small quantities of fresh leaf tissue. Phytochem. Bull. 19: 11-15.

Felsenstein, J. 1985. Confidence limits on phylogenies: An approach using the bootstrap. Evolution 39: $783-791$.

Halle, N. 1968. Nouveau genre de Gardéniées d'Afrique, voisin de Didymosalpinx Keay emend. Adansonia sér. 2, 8: 367-372.

Huelsenbeck, J.P. \& F. Ronquist. 2001. MrBayes. Bayesian inference of phylogeny. Bioinformatics 17: 754-755.

Igersheim, A. 1993. The character states of the Caribbean monotypic endemic Strumpfia (Rubiaceae). Nordic J. Bot. 13: 545-559.

Jordan, W.C., M.W. Courtney \& J.E. Neigel. 1996. Low levels of interspecific genetic variation at a rapidly evolving chloroplast DNA locus in North American duckweed (Lemnaceae). Amer. J. Bot. 83: 430-439.

Keay, R.W.J. 1958. Randia and Gardenia in West Africa. Bull. Jard. Bot. Natl. Belg. 28: 15-72.

Maddison, D.R. \& W.P. Maddison. 2002. MacClade 4: analysis of phylogeny and character evolution, version 4.01. Sinauer Associates, Sunderland, Massachusetts.

Mendenhall, M. 1994. Phylogeny of Baptista and Thermopsis (Leguminosae) as inferred from chloroplast DNA and nuclear ribosomal DNA sequences, secondary chemistry, and morphology. $\mathrm{PhD}$ dissertation, University of Texas.

Mouly, A. 2007. Systématique de la tribu des Ixoreae A.Gray (Rubiaceae); phylogénie, biogéographie et taxonomie. Thèse de doctorat, Muséum National d'Histoire Naturelle, Paris, France.

Persson, C. 2000. Phylogeny of Gardenieae (Rubiaceae) based on chloroplast DNA sequences from the rps16 intron and trnL(UAA)-F(GAA) intergenic spacer. Nordic J. Bot. 20: 257-270.

Posada, D. \& K.A. Crandall. 1998. Modeltest: testing the model of DNA substitution. Bioinformatics 14: $817-818$.

Puff, C., E. Robbrecht, R. Buchner \& P. De Block. 1996. A survey of secondary pollen presentation in the Rubiaceae. Opera Bot. 7: 369-402.

Robbrecht, E. 1979. The African genus Tricalysia A.Rich. (Rubiaceae-Coffeeae). 1. A revision of the species of subgenus Empogona. Bull. Jard. Bot. Natl. Belg. 49: 239-360.

Robbrecht, E. 1980. The Hypobathreae (Rubiaceae-Ixoroideae) 1. Delimitation and division of a new tribe. Bull. Jard. Bot. Natl. Belg. 50: 69-77.

Robbrecht, E. 1982. The African genus Tricalysia A.Rich. (Rubiaceae-Coffeeae). 2. Ephedranthera, a new section of subgenus Tricalysia. Bull. Jard. Bot. Natl. Belg. 52: 311-339.

Robbrecht, E. 1983. The African genus Tricalysia A.Rich. (Rubiaceae). 3. Probletostemon revived as a section of subgenus Tricalysia. Bull. Jard. Bot. Natl. Belg. 53: 299-320.

Robbrecht, E. 1986. Studies in tropical African Rubiaceae 10. Morphological observations on the fruits and seeds of Didymosalpinx (Gardenieae). Bull. Jard. Bot. Natl. Belg. 56: 150-154.

Robbrecht, E. 1987. The African genus Tricalysia A.Rich. (Rubiaceae). 4. A revision of the species of section Tricalysia and section Rosea. Bull. Jard. Bot. Natl. Belg. 57: 39-208. 
Robbrecht, E. 1988a. Studies in tropical African Rubiaceae 13. Petitiocodon, a new genus to accommodate Didymosalpinx parviflora (Gardenieae-Diplosporinae). Bull. Jard. Bot. Natl. Belg. 58: $109-120$.

Robbrecht, E. 1988b. Tropical woody Rubiaceae. Opera Bot. Belg. 1: 1-271.

Robbrecht, E. \& J.-F. Manen. 2006. The major evolutionary lineages of the coffee family (Rubiaceae, angiosperms). Combined analysis (nDNA and cpDNA) to infer the position of Coptosapelta and Luculia, and supertree construction based on rbcL, rps16, trnL-trnF and aptB-rbcL data. A new diversification in two subfamilies, Cinchonoideae and Rubioideae. Syst. Geogr. Pl. 76: 85-146.

Robbrecht, E. \& C. Puff. 1986. A survey of the Gardenieae and related tribes (Rubiaceae). Bot. Jahrb. Syst. 108: 63-137.

Ronquist, F., J.P. Huelsenbeck \& P. van der Mark. 2005. MrBayes 3.1 manual, Draft 5/26/2005. http://mrbayes.csit.fsu.edu/mb3.1_manual.pdf.

Ruhsam, M. \& A.P. Davis. 2007. A taxonomic revision of the genus Flagenium Baill. (RubiaceaeOctotropideae). Bot. J. Linn. Soc. 155: 557-570.

Shaw, J., E.B. Licky, J.T. Beck, S.B. Farmer, W. Liu, J. Miller, K.C. Siripun, C.T. Winder, E.E. Schilling \& R.L. Small. 2005. The tortoise and the hare II: Relative utility of 21 noncoding chloroplast DNA sequences for phylogenetic analysis. Amer. J. Bot. 92:142-166.

Simmons, M.P. \& H. Ochoterena. 2000. Gaps as characters in sequence based phylogenetic analysis. Syst. Biol. 49: 369-381.

Stađen, R., K. Beal \&J. Bonfield. 1998. The Staden Package. In: S. Miseners \& S. Krawetz (eds.), Computer methods in molecular biology: 115-130. Humana Press, New York.

Swofford, D.L. 2003. PAUP* 4.0b10: Phylogenetic Analysis Using Parsimony (* and other methods). Sinnauer Associates, Sunderland, Massachusetts.

Taberlet, P., L. Gielly, G. Pautou \& J. Bovet. 1991. Universal primers for amplification of three noncoding regions of chloroplast DNA. Pl. Molec. Biol. 17: 1005-1109.

Tosh, J., A.P. Davis, S. Dessein, P. De Block, S. Huysmans, M.F. Fay, E.F. Smets \& E. Robbrecht. In press. Phylogeny of Tricalysia A.Rich. (Rubiaceae) and its relationships with allied genera based on plastid DNA data: resurrection of the genus Empogona. Ann. Missouri Bot. Gard. 


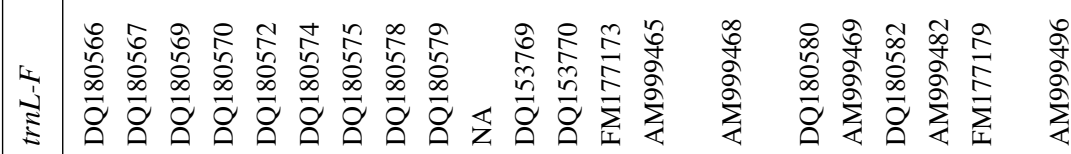

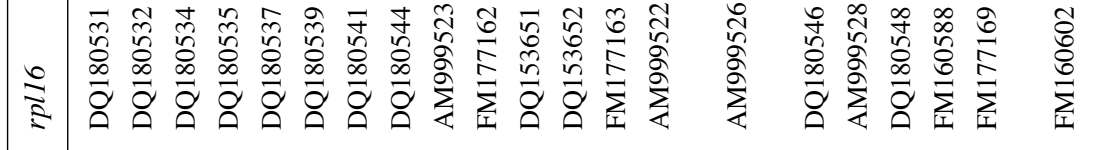

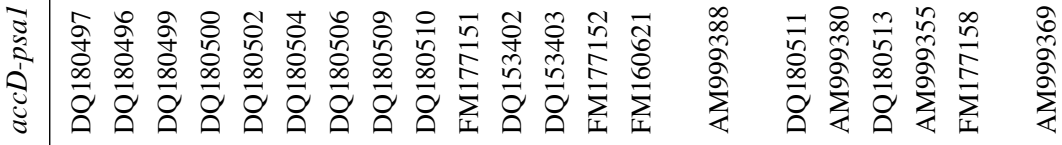

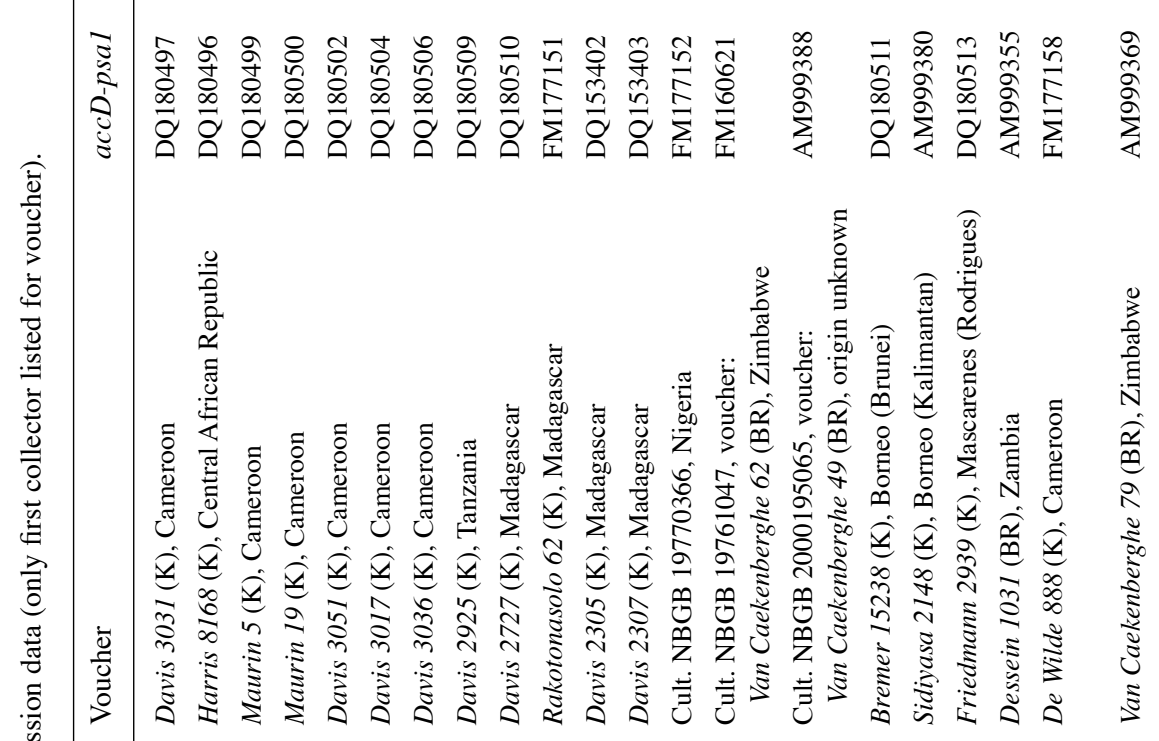




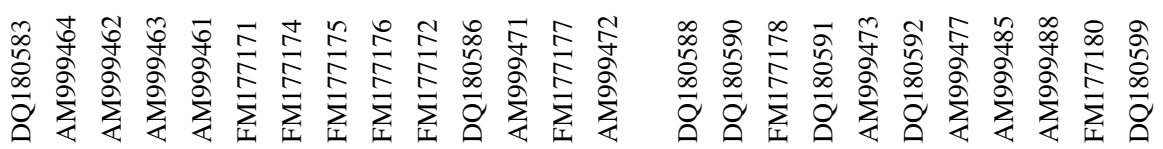

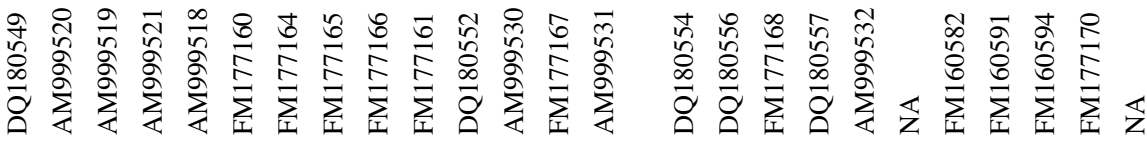

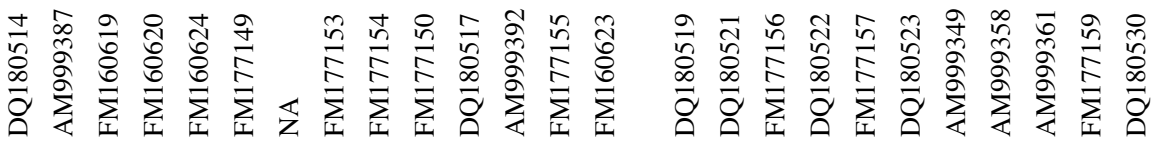

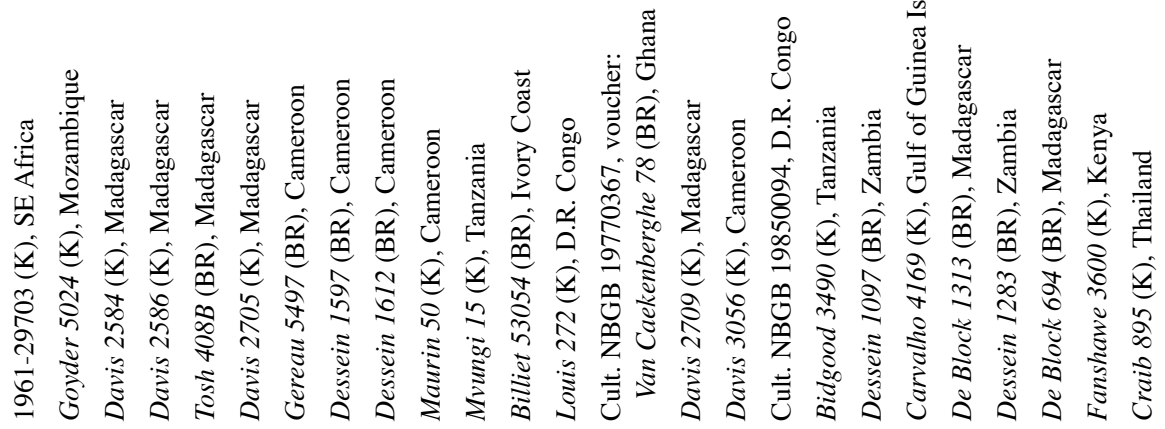
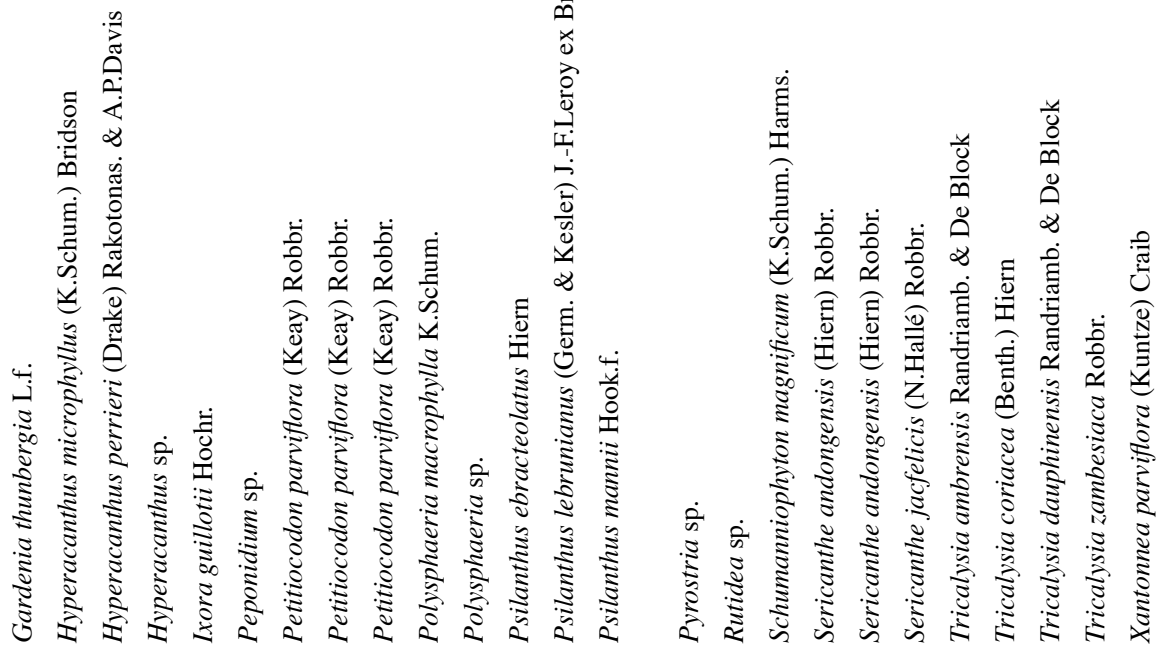